
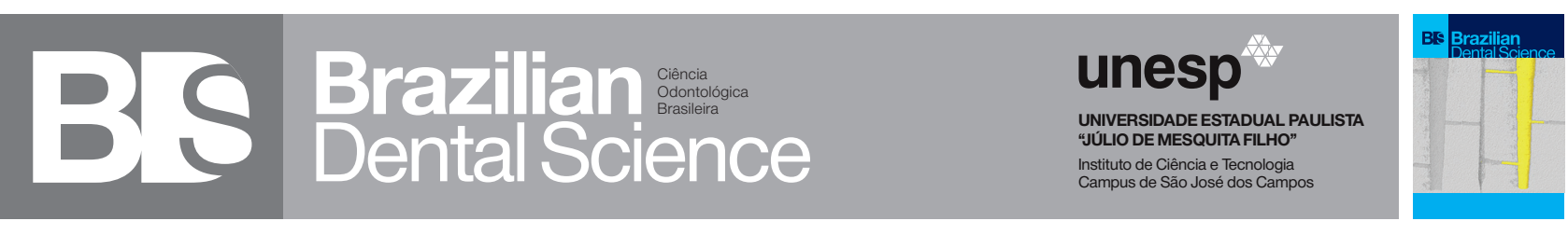

\title{
Multidisciplinary treatment: association among orthodontics, implantodontia and prosthetics. Case report
}

\author{
Tratamento multidisciplinar: associação entre ortodontia, implantodontia e prótese. Relato de caso

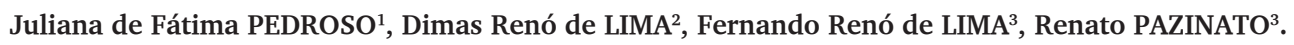 \\ 1 - São Paulo State University (Unesp) - Institute of Science and Technology, São José dos Campos - Department of Diagnosis and Surgery \\ - São José dos Campos - SP - Brazil. \\ 2 - Institute of Science and Technology, São José dos Campos - Department of Social and Pediatric Dentistry - São José dos Campos - SP \\ - Brazil. \\ 3. São Paulo State University (Unesp) - Institute of Science and Technology, São José dos Campos - São José dos Campos - SP - Brazil.
}

\section{ABSTRACT}

Deficiencies in the alveolar ridge, dental migration and malocclusion are conditions that may hamper restorative treatment and thus must be resolved by taking a multidisciplinary approach. This clinical case report is associated with orthodontics, implantology and prostheses for rehabilitation. A 34-year-old male patient presented himself in a private practice complaining of aesthetics and discomfort when chewing. At the clinical examination, teeth numbers 11, 12, 21, 22 and 25 were absent, with a removable partial denture replacing them. Due to the prolonged use of this prosthesis, wear of the artificial teeth and the extrusion of the anterior inferior teeth were present. A depression was also present in the vestibular region of the upper incisors, which did not provide adequate lip support. The tomographic examination revealed that despite the deficiency of the vestibular-lingual bone volume, the remnant in this region allowed for the implantation of implants. Orthodontic treatment was performed for the intrusion of the inferior elements and the alignment of the arches, with the goal of providing more spaces for rehabilitation. Afterward, the patient underwent surgery to install implants in the 11, 21 and 25 regions, concomitantly with bone regeneration in the vestibular region of the upper incisors. During this time, the patient used a new removable partial denture. After eight months, the prosthetic phase was started. Ten years after the end of treatment, the patient is satisfied with the results and performs maintenance every six months.

\section{KEYWORDS}

Tooth movement techniques; Dental Implants; Bone transplantation; Dental prosthesis.

\section{RESUMO}

Deficiências no rebordo alveolar, migração dentária e má oclusão são condições que podem dificultar o tratamento restaurador, exigindo uma abordagem multidisciplinar para sua resolução. Este relato de caso clínico associou ortodontia, implantodontia e prótese para a reabilitação. Paciente do sexo masculino, 34 anos de idade, apresentou-se no consultório particular queixando-se da estética e desconforto ao mastigar. Ao exame clínico, apresentava ausência dos elementos $12,11,21,22$ e 25 , os quais eram substituídos por uma prótese parcial removível. Em decorrência do uso prolongado desta prótese, houve desgastes dos dentes artificiais e extrusão dos inferiores anteriores. Apresentava também uma depressão na região vestibular dos incisivos superiores a qual não proporcionava suporte labial adequado. $\mathrm{O}$ exame tomográfico revelou que, apesar da deficiência de volume ósseo no sentido vestíbulo-lingual, o remanescente nesta região permitia a instalação de implantes. Foi realizado tratamento ortodôntico para intrusão dos elementos inferiores e alinhamento das arcadas, visando ganhar espaços para reabilitação. Após, o paciente foi submetido à cirurgia para instalação de implantes na região do 11 , 21 e 25, concomitantemente com regeneração óssea na vestibular dos incisivos superiores. Durante este tempo, o paciente usou uma nova prótese parcial removível. Passados 8 meses, a fase protética foi iniciada. Dez anos após o término do tratamento, o paciente mostrase satisfeito com os resultados e realiza manutenção semestralmente.

\section{PALAVRAS-CHAVE}

Técnicas de movimentação dentária; Implantes dentários; Transplante ósseo; Prótese dentária. 


\section{INTRODUCTION}

$\mathrm{T}$ he multidisciplinarity of dentistry is similar to that in other areas of health and can be used for cases that require complex rehabilitation. The lack of bone support and tooth movement associated with imbalances in the occlusion are factors related to the loss of dental elements that can make therapy difficult. The joint work of various specialties is paramount for achieving a comprehensive treatment plan.

The loss of teeth affects the stomatognathic system as well as the general health of the patient, negatively impacting his or her quality of life. When tooth loss occurs and the patient remains for a long period without adequate rehabilitation, adjacent teeth and antagonist teeth may move. Malocclusion decreases the masticatory function and impairs hygiene, favoring the development of periodontal disease [1]. The resorption of the alveolar ridge is an unavoidable effect of tooth extraction and may be a significant problem for subsequent therapy with osseointegrated implants [2]. In addition, in the anterior vestibular region, the loss of bone tissue may lead to a lack of superior lip support and aesthetic problems [1].

Conventionally, lost teeth were replaced with partial removable prostheses or fixed prostheses, which require the wearing down of the adjacent teeth and enamel for the preparation of supports. In recent years, however, dental implant therapy has become widely used to replenish the dentition. Implant-supported prostheses present predictable results and have high success rates, with minimal marginal bone resorption in the long term [1]. They are effective and viable for the replacement of teeth, returning the function to edentulous patients, and enabling the recovery of chewing, speech, smiling and swallowing. However, implant therapy can be complex and challenging for patients with insufficient bone tissue and dental arch misalignment [3-5].

In partially edentulous arches, dental migration and maladjustments usually occur in the occlusion, which makes rehabilitation treatment difficult. The mesial movement of teeth into the edentulous spaces decreases the mesio-distal distance for a future implant prosthesis. Extruded teeth may prevent prosthetic treatment due to the absence of an interocclusal space [6]. When disharmony exists in the occlusion, orthodontics can be used to restore the interocclusal space necessary for restorative treatment, to obtain an adequate occlusal plane, to improve aesthetics and to minimize the potential for interference during mandibular excursion movements [6]. The position and alignment of the teeth in relation to the planned restorations must be carefully evaluated and, if necessary, corrected to avoid compromising the prosthetic results.

In cases where the amount of bone tissue is insufficient for installing implants, or if bone volume is desired in aesthetic areas, grafting procedures become necessary. The material used as a graft should have biocompatibility, osteoconduction, adequate mechanical support to provide the necessary volume of regenerated bone, and biodegradability, and it should be replaced with the patient's bone. Depending on their origins, bone substitutes may be the following: allogeneic, of human origin; xenogens, from another species, usually bovine or equine; and alloplastics, produced synthetically [7].

The purpose of this case report is to demonstrate that multidisciplinary treatment may be the conduit of choice for complex rehabilitation. The present case, which spanned 10 years, was associated with orthodontics, implantology and prostheses.

\section{CASE REPORT}

A 34-year-old male patient presented himself at a private practice complaining about aesthetics and discomfort when chewing. Clinical and radiographic examinations (Figure 1) revealed the absence of teeth numbers 11,12 , 21,22 and 25, which were replaced with a partial removable prosthesis. As a result of the prolonged use of this prosthesis, wear of the artificial teeth and the extrusion of the anterior inferior teeth were present (Figure 2). A depression was also present in the vestibular region of the upper incisors, which did not provide adequate lip support (Figure 3).

The tomographic examination revealed that despite the deficiency of the buccal-lingual bone volume, the remnant in this region allowed for the installation of implants (Figure 4). 


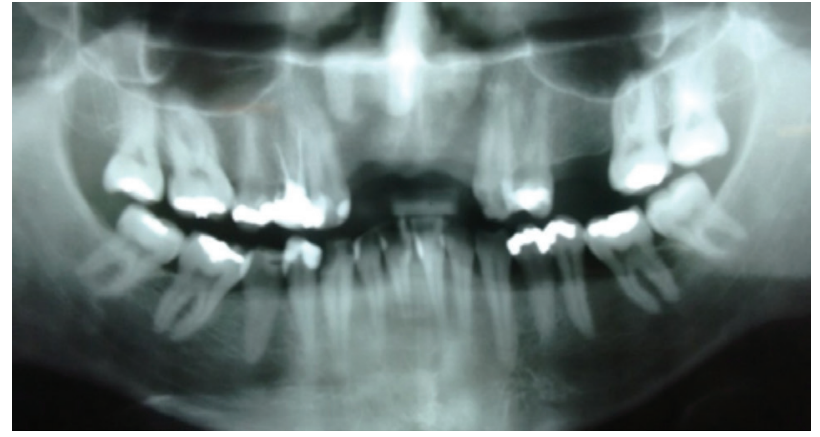

Figure 1- Panoramic radiograph of the patient before the start of treatment.

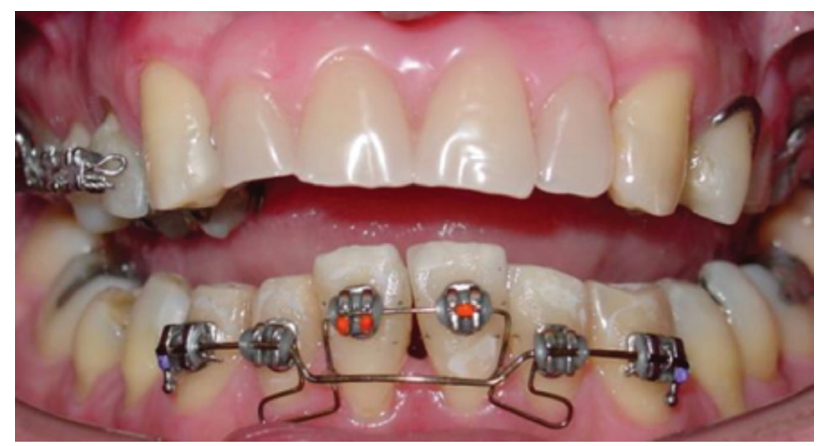

Figure 2 - Initial clinical aspect: observe that teeth 31 and 41 are extruded in relation to the adjacent teeth. At the beginning of the treatment, the patient used a superior partial removable prosthesis.

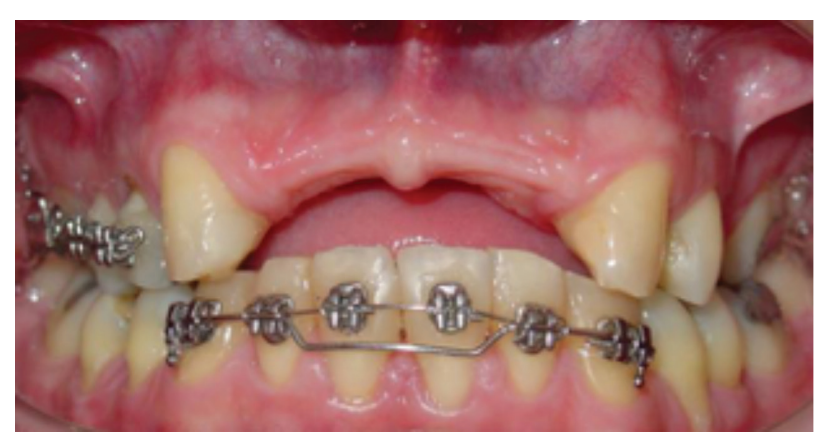

Figure 3 - At the upper edentulous border, the patient presented a depression in the anterior region, which damaged the labial support.

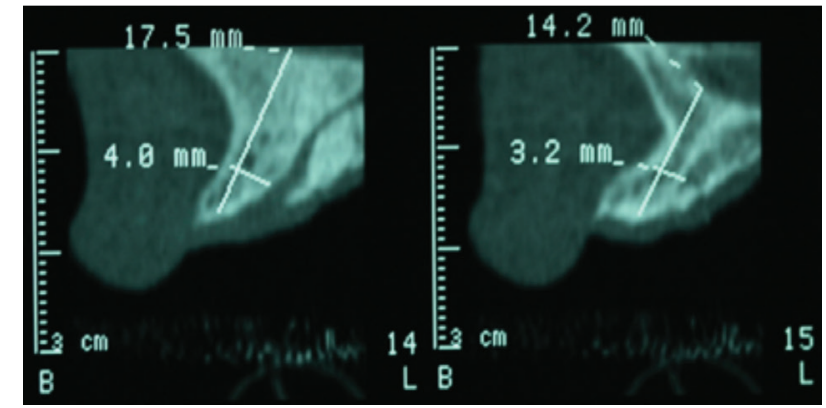

Figure 4 - Computed tomography of the upper anterior region displayed the bone availability for the implantation of implants.

Based on the data collected through the clinical and imaging exams, a treatment plan was established to rehabilitate the patient, beginning with orthodontics for the correction of spaces, followed by bone regeneration in the upper anterior region and the installation of implants in the edentulous areas. The entire treatment plan was explained to the patient, including its advantages and disadvantages. The patient accepted and agreed to the proposed treatment by signing a consent form (Annex 1).

Initially, orthodontic treatment was performed for the intrusion of the inferior elements and the alignment of the arches. To provide space for the maxillary incisors, the diastema existing between the maxillary premolars was eliminated, and wear on the proximal surface of tooth 14 were performed. In the lower arch, the incisors were aligned and leveled, as the central incisors were extruded. Still, in the lower arch, the incisals of teeth 32 and 42 were inclined due to the wear resulting from the superior partial removable prosthesis. Brackets were glued to the canines and lower incisors to align and level these teeth. With the intention of assisting the distalization of teeth 13 and 14, an orthodontic button was attached to the partial removable prosthesis to anchor two elastics, one for the lingual area, and another for the vestibular area, to prevent the teeth from rotating. 
After the complete movement of teeth 13 and 14, the partial removable prosthesis was replaced to release teeth 23 and 24 to be distalized, thus further increasing the space available for the upper incisors (Figure 5). An intermaxillary elastic was used to approximate the canines on the left side to obtain a canine guide. After the brackets were removed, a fixed restraint was installed on the lower anterior teeth. The upper arch restraint was maintained until the temporary crowns were installed over the implants.

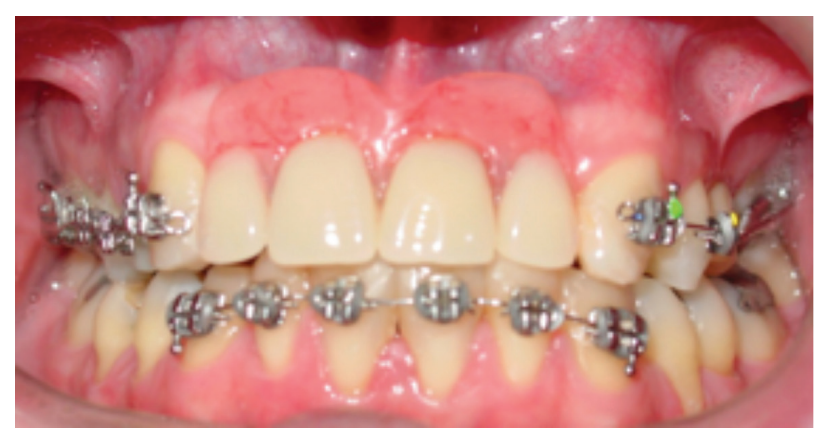

Figure 5 - During orthodontic treatment, a new superior provisional PPR was created.

Afterward, the patient underwent surgery to install implants external hexagon implant system - Conexão, in the regions of teeth 11,21 and 25 , with dimensions $3,75 \mathrm{x}$ $11,5,3,75 \times 11,5$ e $5,0 \times 11,5$, respectively (Figures 6 and 7).

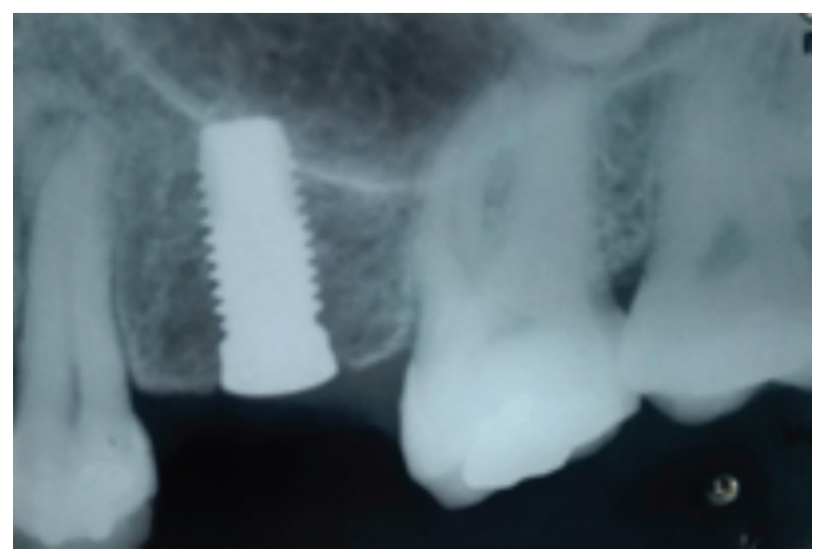

Figure 6 - Periapical radiograph of the implant in the tooth 25 region six months after the installation surgery..

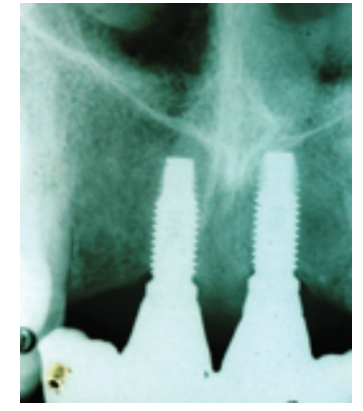

Figure 7 - Periapical radiograph of the implants in the anterosuperior region six months after the installation surgery.

Concomitantly with the implant installation with bone regeneration in the vestibular region of the upper incisors. The graft used was bovine bone GenOx Org, Genius $\AA$, followed by the placement of bovine membrane GenDerm, Genius ${ }^{\circledR}$. Due to the bone grafting procedure, it was necessary to wear down the superior provisional partial removable prosthesis so that it would fit better (Figure 8).

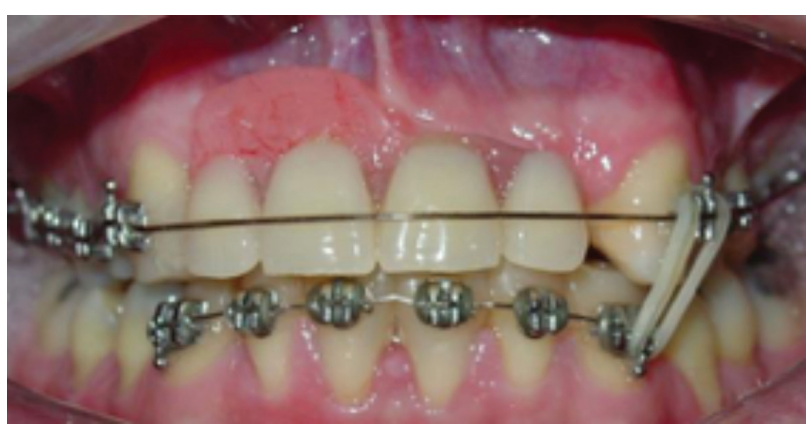

Figure $\mathbf{8}$ - After bone graft surgery, it was necessary to wear down the anterior superior partial removable prosthesis area to better accommodate the prosthesis.

After eight months of implant installation and boneregeneration, temporaryacryliccrowns were installed (Figure 9). After yet another six months, the definitive metaloceramic crowns were fabricated (Figure 10). 


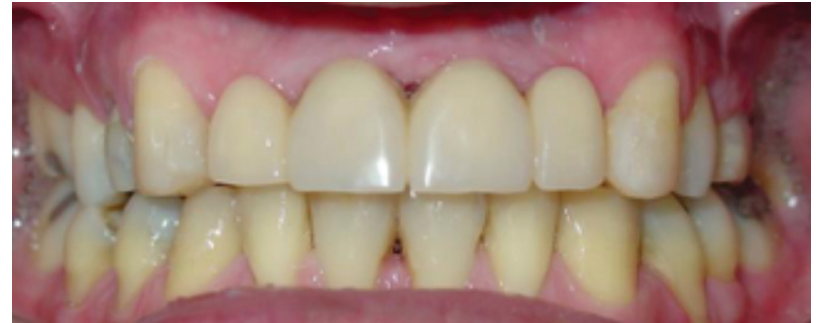

Figure 9 - Temporary crowns made of acrylic resin installed on the implants.

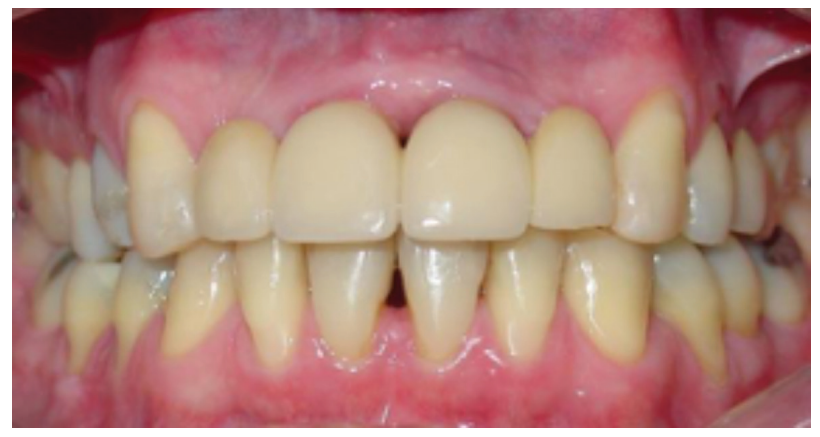

Figure 10 - Prostheses on implants in metaloceramics.

Ten years after the end of treatment, the patient is satisfied with the results and performs maintenance every six months. The implant prostheses and dental alignment, along with the gingival tissue, did not present changes during follow-up (Figure 11). A radiographic examination revealed the stability of the implants and bone tissue (Figures 12 and 13). The lower anterior incisors and their supporting tissues did not display pathologies after 10 years of orthodontic intrusion (Figure 14).

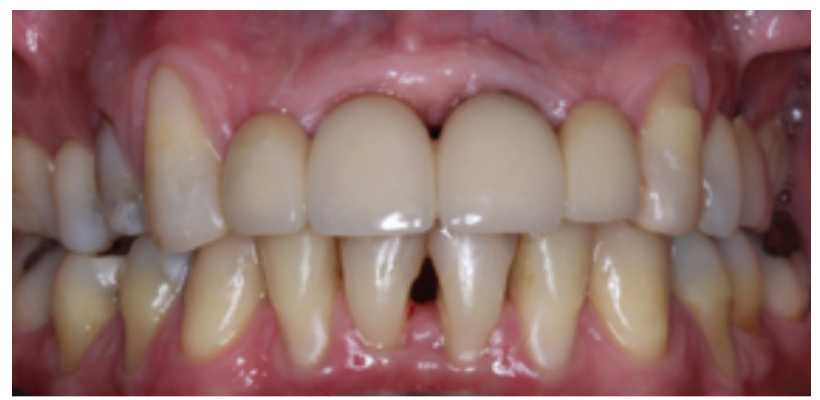

Figure 11 - After 10 years of the end of the treatment, stability of the crowns on the implants is observed.

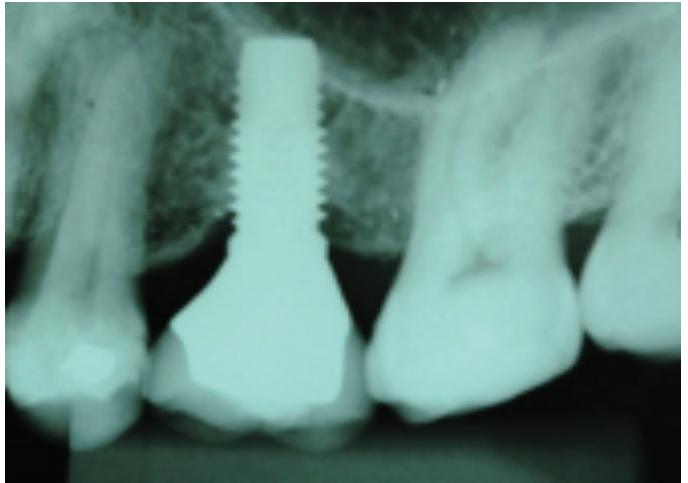

Figure 12 - Periapical radiograph of the implant of the tooth 25 region 10 years after treatment.

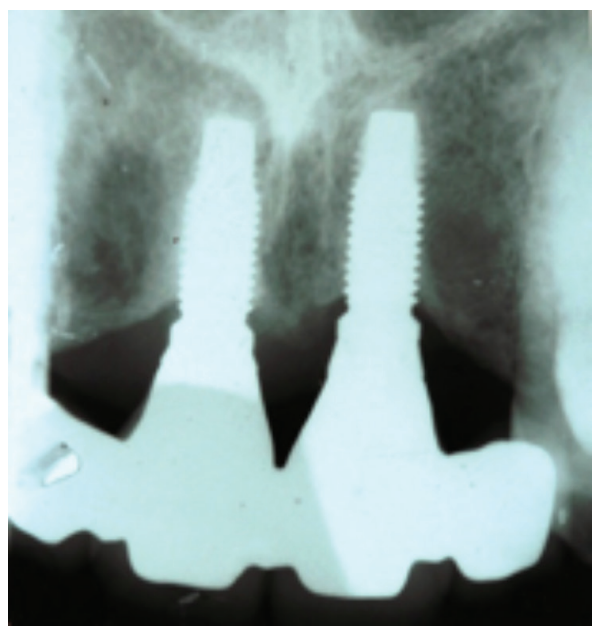

Figure 13 - Periapical radiograph of the upper anterior region indicating the stability of the osseous tissue after 10 years of follow-up.

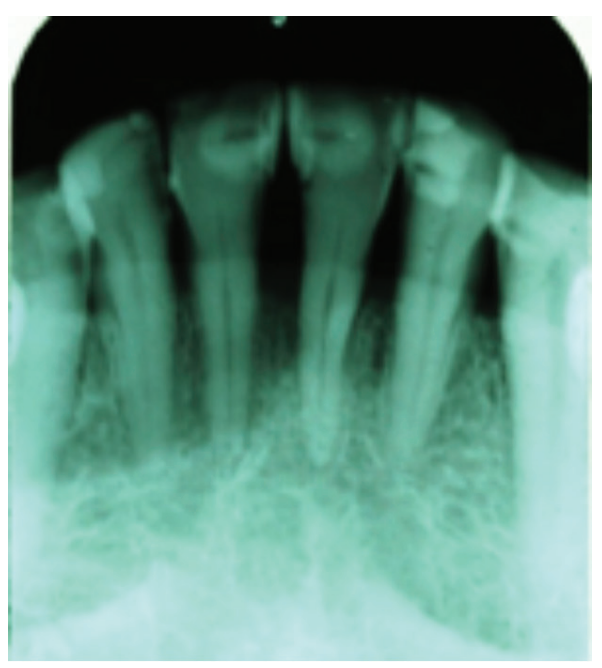

Figure 14 - Periapical radiograph of anterior lower teeth 10 years after orthodontic intrusion is completed. 


\section{DISCUSSION}

One of the main purposes of prosthetic treatment is to restore masticatory function in edentulous patients [8]. A partial removable prosthesis provides reduced masticatory capacity due to the poor retention and stability of this type of prosthesis [9]. In a partial removable prosthesis, occlusal forces move the base of the prosthesis toward the ridge direction, causing rotational movements and producing forces on the abutments and soft tissues [10-12]. Replacing missing teeth with dental implants can solve this problem. Dental implant therapy improves masticatory function, thus providing greater patient satisfaction and an improved quality of life [13]. The dental implant is one of the most preferred treatment options, as it is the treatment that is closest to the natural dentition [14]. Gonçalves (2014) and Gonçalves (2015) demonstrated through a clinical study that masticatory capacity and nutritional quality exhibited better results in patients who used dentures on implants compared with those using partial removable prostheses. In the present case, the patient before starting treatment complained of discomfort during mastication due to the use of a partial removable prostheses. After the completion of treatment, the patient reported improvement in this aspect, with a gain in his quality of life $[15,16]$.

In addition to restoring function, oral rehabilitation in the toothless patient should also be concerned with regaining his or her facial shape. A complete plan needs to identify the need for bone augmentation procedures, and for this, it is necessary to understand that the alveolar ridge atrophy process affects not only the bone tissue but also the soft tissues that overlap it. Systematic reviews have revealed that horizontal bone loss is $29-63 \%$ and vertical bone loss 11-22\% after six months of tooth extraction. Rapid reductions of bone tissue occur in the first 3-6 months, followed by gradual reductions in the following periods. During the post-extraction healing stage, clinical loss in width is greater than the loss in height, in both clinical and tomographic evaluations $[17,18]$. Thus, alveolar ridges usually present a reduced amount of bone tissue, such as in the case of this patient, where despite the availability of bone for implants, the reduced volume of vestibule-lingual bone has negative aesthetic effects, such as a lack of superior lip support. The loss of the natural dentition results in the gradual reabsorption of the alveolar process and causes changes in the facial muscles and, consequently, a change in the facial morphology. The upper lip is dependent on the dentition and on the alveolar bone for satisfactory support. With the loss of superior buccal bone support, the nasolabial angle increases, the vermilion of the lip is less evident, and an apparent shortening of the lip takes place, with the consequent loss of lip support [19]. For the present case, GenOx Org bovine bone graft, Genius ${ }^{\circledR}$, followed by GenDerm membrane placement, Genius ${ }^{\circledR}$, was used immediately after the installation of the implants in the upper anterior region. The goal was to increase the vestibular bone volume to improve the patient's facial appearance.

The correction of overbite can be achieved through the intrusion of the anterior teeth or the extrusion of the posterior teeth. Among the various types of orthodontic movements, the intrusion of the anterior teeth is considered a complex movement due to the difficulty of obtaining real intrusion, that is, body intrusion and not just the inclination of the teeth. The intrusion movement is much more difficult to achieve compared with the extrusion movement, as the periodontal fibers' orientation causes them to strongly resist movement $[20,21]$. The orthodontic intrusion of the teeth is associated with three main concepts. First, to obtain anchorage, the apparatus must be rigid and include as many teeth as possible; second, the point of the application of the force must be through the center of resistance; third, the recommended amount of force to intruate a single rooted tooth is $10 \mathrm{~g}$ to $20 \mathrm{~g}(0.098 \mathrm{~N}$ to $0.196 \mathrm{~N}$ ) [6]. Traditional fixed orthodontic appliances are often preferred to removable appliances because the result of the treatment is less dependent on patient compliance. In the intrusion movement, the force is concentrated over a small area in the apical region of the periodontal ligament, regardless of the point of the application of the orthodontic force, and light forces are required to produce appropriate pressure $[6,22]$. 
Intrusion movement is more associated with root resorption and pulpal alterations than any other type of induced movement is $[23,24]$. The distribution of force along the dental root and the surrounding bone structure is more important than the intensity or range of the force application is [25]. The force applied on the crown causes a movement that associates vestibular intrusion and inclination. Consequently, the greatest amount of force is concentrated at the apex, favoring the anoxia of the periodontal ligament and the death of the cementoblasts, thus resulting in root resorption [26]. Sabuncuoglu (2015) demonstrated that small regressive changes occur in the pulp tissue as a result of the intrusion movement, and changes in pulp blood flow levels tend to be reversible. During the intrusive movement of anterior teeth, the posterior teeth tend to extrude. Adequate control of the posterior teeth, through rigid stabilization, decreases the magnitude of the force used for intrusion $[27,28]$. In the present case, we observed that after 10 years, the periodontal tissues in the lower incisors are stable after the intrusion movements. Thus, this orthodontic approach, when well indicated and properly applied, can be an excellent treatment option for bite corrections and for providing more interocclusal space.

For 35 years, implants have been widely used to restore lost teeth. The abutment-implant interface has an external or internal connection. At the time of the installation of the implants in the present case, the external connection was predominant, with the most commonly used one being composed of an external hexagon. The disadvantages of external connections are now known, such as the small distance between the prosthesis and the implant head, which creates greater stress on the connection and the greater possibility of bacterial infiltration. In addition, mismatch at the abutment-implant interface results in the colonization of bacteria, which can cause bone loss around the implant, thus leading to failures. Despite this context, this case report demonstrates that it was possible to achieve clinical and aesthetic success with the external connection, even after 10 years of follow-up. In an attempt to improve the properties and performance of implants, many systems with various connections are currently available in the market, with internal connections and the morse connection being the most widely used. One of the main causes of implant failure is periimplantite: a destructive inflammatory process that occurs around osseointegrated implants due to the colonization of bacteria. Even in the case of external connections, the patient's case is stable, with no signs of inflammation. Studies have indicated that the bacterial microleakage of external connections resembles that of internal connections when the amount of torque in the screw is increased [29-32]. The present case demonstrated that the external connection used can produce positive results in the long term. In addition, the patient returns to the office to perform maintenance every six months, a fact that may favor the success of this type of connection.

\section{CONCLUSION}

The purpose of this multidisciplinary treatment was to create adequate space for rehabilitation with implants, with the goal being to establish a functionally and aesthetically satisfactory occlusion. The treatment plan involving Implantology, orthodontics and prosthodontics proved to be effective for this challenging case. After a 10-year follow-up, the prostheses are stable, reaffirming the use of a multidisciplinary approach.

\section{REFERENCES}

1. Sekine H, Miyazaki H, Takanashi T, Furuya K, Matsuzaki F, Taguchi T, et al. Dental implant treatment after improvement of oral environment by orthodontic therapy. Bull Tokyo Dent Coll. 2012;53(3):109-17.

2. Agarwal G, Thomas R, Mehta D. Postextraction maintenance of the alveolar ridge: rationale and review. Compend Contin Educ Dent. 2012 May;33(5):320-4, 326; quiz 327,336.

3. de Molon RS, de Avila ED, Cirelli JA, Cardoso Mde A, Capelozza-Filho L, Borelli Barros LA. Optimizing maxillary aesthetics of a severe compromised tooth through orthodontic movement and dental implants. Case Rep Dent. 2014;2014:103808.

4. de Almeida Cardoso M, de Molon RS, de Avila ED, Guedes FP,Battilani Filho VA, Capelozza Filho L, et al. Facial and occlusal esthetic improvements of an adult skeletal Class III malocclusion using surgical, orthodontic, and implant treatment. Korean J Orthod. 2016 Jan;46(1):42-54.

5. Ogle OE. Implant surface material, design, and osseointegration. Dent Clin North Am. 2015 Apr;59(2):505-20.

6. Slighly C, Ramos V Jr,Brousseau S. Orthodontic single tooth intrusion with a removable interocclusal device: A clinical report. JProsthet Dent. 2013 May; 109(5):283-6.

7. Mariano Sanz, Fabio Vignoletti. Key aspects on the use of bone substitutes for bone regeneration of edentulous ridges. Dental Materiais 31 (2015) 640-647. 
8. Fueki K, Igarashi Y,Maeda Y,Baba K, Koyano K, Akagawa Y,etal. Factors related to prosthetic restoration in patients with shortened dental arches: a multicentre study.J Oral Rehabil. 2011;38:525-532.

9. Van der BiltA, Van Kampen F,Cune M. Masticatory function with mandibular implant-supported overdentures fitted with differentattachment types. European Journal of Oral Sciences. 2006;114:191-6.

10. Ohkubo C, Kobayashi M, Suzuki Y, Hosoi T. Effect of implant support on distal-extension removable partial dentures: in vivo assessment. International Journal of Oral and Maxillofacial Implants. 2008;23:1095-101.

11. Phoenix RD, CagnaDR, De Freest CF.Stewart's Clinical Removable Partial Prosthodontics, 4th ed. Hanover Park, L:: Quintessence;2008.

12. Carr AB, Brown DT,McCracken WL. McCracken's Removable Partial Prosthodontics, 12th edn. St. Louis, Mo: Elsevier Mosby;2011.

13. Att W,Stappert C. Implant therapy to improve quality of life. Quintessence Int. 2003 Sep;34(8):573-81.

14. Alam MK, Rahman SA, Basri R, Sing Yi TT, Si-Jie JW, Saha S. Correction: Dental Implants - Perceiving Patients' Satisfaction in Relation to Clinical and Electromyography Study on Implant Patients. PLOS ONE. 2015; 10(11):e0143902.

15. Gonçalves TM, Campos CH, Rodrigues Garcia RC. Mastication and jaw motion of partially edentulous patients are affected by different implant-based prostheses. J Oral Rehabil. 2014 Jul;4117):507-14.

16. Gonçalves TM, Campos CH, Garcia RC. Effects of implant-based prostheses on mastication, nutritional intake, and oral health-related quality of life in partially edentulous patients: a paired clinical trial. Int J Oral Maxillofac Implants 2015;30:391-6.

17. Tan WL, Wong TL, Wong MC, Lang NP.A systematic review of post-extractional alveolar hard and soft tissue dimensional changes in humans. Clin Oral Implants Res. 2012Feb; 23 Suppl 5:1-21.

18. Van der Weijden F,Dell'AcquaF,SlotDE. Alveolar bone dimensional changes of post-extraction sockets in humans: a systematic review. J Clin Periodontol. 2009 Dec;36(12):1048-58.

19. Sutton DN, Lewis BR, Patel M, Cawood JI. Changes in facial form relative to progressive atrophy of the edentulous jaws. Int J Oral Maxillofac Surg.2004 0ct:33(7):676-82.

20. Oliveira CSBM. Yamazaki MS. Meio DBC Jr., Meros GC, Paranhos LR. Mechanics for intrusion of the anterior teeth. Rev ClinOrtod Dental Press. 2010 agoset;9(4):72-83
21. Salehi P,Gerami A, Najafi A, Torkan S. Evaluating Stress Distribution Pattern in Periodontal Ligament of Maxillary Incisors during Intrusion Assessed by the Finite Element Method. JDent(Shiraz). 2015Dec; 16(4):314-22.

22. Saga AY,Maruo H, Argenta MA, Maruo IT, Tanaka OM. Orthodontic intrusion of maxillary incisors: a 3D finite element method study. Dental Press J Orthod. 2016 Jan-Feb;21(1):75-82

23. Abtahi M, Eslami N, Abadi RZ, Rezaei SP. The effect of intrusive orthodontic force on dental pulp of adults versus adolescents. Dent Res J (Isfahan). 2016 Jul-Aug;13(4):367-72.

24. Claro CAA, Abrão J, Reis SAB, Laganá DC. Stress distribution in a photoelastic model resulting from intrusion of mandibular incisors using Ricketts utility arch. Dental Press J. Orthod. 2011;16(5) Maringá Sept./Oct. 2011.

25. Consolaro A. Entre Rev DentPress OrtodOrtop Facial. 2002:7(3),7-16.

26. Consolaro A. Reabsorções dentárias nas especialidades clínicas. 2 ed.. Maringá: Dental Press;2005.Cap. 12, p. 353-401.

27. SabuncuogluFA, Ersahan S. Comparative evaluation of pulpal blood flow during incisor intrusion. Aust0rthod J. 2015 Nov;31(2):171-7.

28. Sifakakis I, Pandis N, Makou M, Eliades T, Bourauel C. Forces and moments on posterior teeth generated by incisor intrusion biomechanics. OrthodCraniofac Res. 2009 Nov;12(4):305-11.

29. Verdugo CL, Núñez G J, Avila AA, San Martín CL. Microleakage of the prosthetic abutment/implant interface with internal and external connection: in vitro study. Clin Oral Implants Res. 2014;25:1078-83.

30. Smith NA, Turkyilmaz I. Evaluation of the sealing capability of implants to titanium and zirconia abutments against Porphyromonas gingivalis, Prevotellainter media, and Fusobacterium nucleatum. J Prosthet Dent. 2014;112:561-67.

31. Cavusoglu Y,Akça K, GürbüzR, Cehreli MC. A pilot study of joint stability at the zirconium or titanium abutment/titanium implant interface. Int $\mathrm{J}$ Oral Maxillofac Implants. 2014;29:338-43.

32. Mishra SK, Chowdhary R, Kumari S. Microleakage at the different implant abutment interface: a systematic review. JClin Diagn Res. 2017 Jun;11(6):ZE10ZE15. doi:10.7860/JCDR/2017/28951.10054.

\section{Juliana de Fátima Pedroso}

(Corresponding address)

Av. Francisco José Longo, 777 - Jardim São Dimas, São José dos Campos - SP

E-mail: juliana.pedroso@ict.unesp.br

Date submitted: 2018 Jul 07

Accept submission: 2018 Jun 13 